\title{
Reviews
}

Henry Ford, Today and Tomorrow. Productivity Press, Cambridge, MA, 1988, 400 pages, US\$24.95.

Taiichi Ohno, Toyota Production System (Beyond Large-Scale Production). Productivity Press, Cambridge, MA, 1988, 176 pages, US\$39.95.

Hajime Karatsu, Tough Words for American Industry. Productivity Press, Cambridge, MA, 1988, 192 pages, US\$25.95.

Productivity Press of Cambridge, MA, has reprinted Henry Ford's 1926 classic Today and Tomorrow. Just in (the nick of) time!

This is a book of management genius which proves beyond reasonable doubt that so called Japanese-style management of today not only has its roots in America, but is a full-blooded American management system in its nature and culture.

It is the management system we have now based upon extreme division of labor, hierarchical command, separation of external ('absent') owners from employees, reliance on labor (or money) rather than knowledge, debt-based management, dependency and inflexibility, financial-ratio view of technology, lowest possible quality, 'consumer beware' attitude, mass production and mass consumption, and incompetence and global provincialism of top management - which is deeply unAmerican and represents historical aberration. This system of central command, predictive planning, and mass production, intermittently successful during wars and crises and their immediate aftermaths, has been evolving roughly from the times of New Deal until the early 1980s. It delivered employment, mass consumption and the degradation of craftmanship and the quality of working life.

If Henry Ford could make his vision a reality in

IOS

Human Systems Management 8 (1989) 175-182
America, it would be the U.S.A. today which would be the strongest proponent and practitioner of Japanese-style management: the interruption and socialistic command system of the 1930-1980 era would have never occurred.

Tomáš Bat'a of the Bat'a system and Taiichi Ohno of the Toyota's Just-In-Time systerm, both freely and proudly admit that they have learned from Henry Ford. Neither Bat'a system nor Ohno's admissions are acceptable to the Harvard Business Reviews of today's America: they do not believe in Henry Ford!

Why?

It is sufficient to quote Henry Ford directly:

The notion that money is the life blood of business and that if you can control money you can control business has just enough foundation to make them seem real. ... presently people everywhere will learn to disregard the teachings of both professional financiers and professional reformers, just as we have learned to disregard them here in the United States.

How wrong was Henry Ford in 1926! We have not 'learned to disregard them' yet. Their heydays were yet to come. But Henry was so sure:

To confuse business with the money power is to make one thing of two and to unite elements which naturally oppose each other. A business cannot serve both the public and the money power. As a matter of fact, the money power has always lived more by exploiting or wrecking business than by the service of business. There are signs, however, that this may be on the mend.

It is only in the very late 80 s that we are learning that ownership and employment should not be separated. External 'absentee' ownership Ford called 'dead' money - as did James F. Lincoln of the Lincoln Electric, who put stockholders always last as residual claimants (for good reasons) - while employee profit-sharing and co-investment he called 'live' money: 
Money put into business as a lien on its assets is dead money. When industry operates wholly by the permission of 'dead' money, its main purpose becomes the production of payments for the owners of that money. The service to the public has to be secondary. If quality of goods jeopardizes these payments, then the quality is cut down. If full service cuts into the payments, then service is cut down. This kind of money does not serve business. It seeks to make business serve it.

Live money goes into the business to work and to share with the business. It is there to be used. It shares whatever losses there may be. Live money in business is usually accompanied by the active labour of the man or men who put it there. Dead money is a sucker-plant.

Henry Ford, Tomáš Bat'a, James F. Lincoln, Fletcher Jones and other undisputed geniuses of management, today mostly forgotten, believed that a business which can bring itself to the point where it attracts the attention of money should be able to continue on its own feet without being financed:

Another rock on which business breaks is debt. Debt is nowadays an industry. The debt motive is, basically, a slave motive.

When business goes in debt it owes a divided allegiance. The scavengers of finance, when they wish to put business out of running or secure it for themselves, always begin with the debt method. Once on the road, the business has two masters to serve, the public and the speculative financier. It will scrimp the one to serve the other, and the public will be hurt, for debt leaves no choice of allegiance.

Of course, the hatred of financiers by all great entrepreneurs, longing for freedom, independence and flexibility, was always great. Only the modern professional 'operateur' does not care for such things:

Business has freed itself from domineering finance by keeping within itself its earnings. Business that exists to feed profits to people who are not engaged in it, stands on a false basis. This is being so well understood that it has become a part of the creed of commerce that the service of business is wholly to the public and that the profits of business are due, first, to the business itself as a serviceable instrument of humanity, and then to the people whose labour and contributions of energy make the business a going concern.

The record of financiers in business affairs is full of disaster. If finance had the far-flung power that alarmists say it has, America, like Europe, would be filled with ragged peasants.

Here again, Henry Ford was wrong: the heydays of financiers were only to come and with vengeance: whole generations of MBAs have been sacrificed to leverage, leveraged buyouts or short-term paybacks and sentenced to eternal innocence of any understanding of business as Ford's and Bat'a's 'Service to the Public'.

In 1988, the quintessential American entrepreneur Ross Perot, responding to how he would run General Motors, wrote in Forbes:

Financial people will be responsible for maintaining accounting information. People who know how to build cars and serve customers will make the product decisions. Accountants will not sap the productivity of car builders with guerilla warfare.

Starting today, GMers are going to use brains, wits, creative abilities and initiative as substitutes for money. GM will use money like a scalpel not a bulldozer. Problems facing GM have little to do with capital expenditures and everything to do with tapping the full potential of the GM team. If spending money were the answer, GM would already be the first and best at everything it does.

Does Ross Perot represent the first glimmer of American management renaissance? Coming back to the roots of Henry Ford? Who can tell?

In the early 1920s the National Association of American Engineers (NAAE) appointed a task force aimed at helping streamline industries that proved wasteful and inefficient suppliers of US Armed Forces during World War I. Herbert Hoover, the future President of the United States, was appointed director of the Commission. Tomás Bat'a read the Hoover Commission report and the Bat'a system was born. In the U.S. the report and 
its recommendations went largely unnoticed and unheeded.

Ford on inventory, being the precursor of JustIn-Time:

Having on hand twice as much material as is needed - which is another way of saying twice as much stored human labour is needed - is precisely the same as hiring two men to do the job that one man ought to do.

Why is it that so few in the U.S.A. have listened to Henry Ford? Why didn't we develop the just-intime philosophy, but evolved a wasteful operationsresearch inventory theory and similar 'cost-minimizing' methodologies instead?

Ford on waste and quality, destroying the notion of quality 'control':

Reclaiming the scrap left over after production is a public service, but planning so that there will be no scrap is a higher public service.

Why not making it right the first time through? Ford asks. 'We do not know and it ain't our job,' quality 'control' staticians answer, 'Our job is to catch all the bad that did get through, at the lowest cost.'

In 'Toyota Production System', Taiichi Ohno, the 'founding father' of Just-In-Time, credits Henry Ford directly and without hesitation:

I, for one, am in awe of Ford's greatness, I think that if the American king of cars were still alive, he would be headed in the same direction as Toyota.

We see that automation and the work-flow system invested and developed by Ford and his collaborators were never intended to cause workers to work harder and harder, to feel driven by their machines and alienated from their work.

Ford's successors, however, did not make production flow as Ford intended. They ended up with the concept 'the larger the lot size, the better.'

Tracing the conception and evolution of work flow by Ford and his associates, I think their true intention was to extend a work flow from the final assembly line to all other processes; that is, from machine processing to the die press that corresponds to the earlier processes in our Toyota system.

So, Toyota's Just-In-Time is not a Japanese system, but Ford's fully American system of quality and service-oriented human system management. The question therefore is not whether or not to adapt 'Japanese' or any other management system, but why have we ever abandoned our own 'American' system of management, substituted Fords for Iacoccas, and tried to manage by fiddling with the exchange rates and debt rather than improving products and their production? Because we do not ask such questions, we do not have the answers.

The current aberration of the war-like management 'system' of strict hierarchical command, based on extreme specialization and the 'it ain't my job' attitude, is about as American as a Kalashnikov rifle.

Finally, in 'Tough Words for American Industry,' Hajime Karatsu faults American business for seeking political, financial or legal solutions to managerial problems. Where we should talk about quality, customer, workers' pride and global competition, we talk about 'lowering the dollar' (true!), increasing debt (true!) and establishing trade barriers to 'Fortress Europe'. Politics, barriers, 'fortresses', TV advertising, governmental intervention, net present values and leveraged buyouts are popular words, but customer, public, employees, quality, and global business ecosystem are not.

Workplace is a temple of business: clean, immaculate, efficient, harmonious and sacrosanct, not an undisciplined stable of low quality, low efficiency and dirt: Americans have to relearn how to behave in the temple of business.

We live in the era of knowledge as a dominant form of capital. But knowledge is coordination of action, not just having 'brilliant' ideas or speculating in prices.

We think in terms of binary values and Cartesian coordinates: black/white, 0/1, good/bad, American/Japanese and so on. The world has changed, it is not this way anymore, if it ever was. American managers are out of touch with the reality and the world. Their faulty and simplistic 
theoretical perspectives (like 'lower the exchange rates') prevent them from experiencing or responding to even the inadequate data in front of them.

Americans have invented the gray flannel suit where they should have discovered that human beings are not robots. The GM/Toyota NUMMI plant in California, with the benefit of 'Japanese' (understand real American) management system, outperforms GM's expensive and incompetent 'experiments' (or rather, 'perestroikas') in robotics. Karatsu echoes Ohno:

I am quite sad, because all the things we are doing today, we learned almost all from the Americans. I tell young product engineers that America is still good, but they don't believe me.

It is difficult to do justice to even the three books recently published by the Productivity Press. It is probably more useful to publish their address:

P.O. Box 3007, Cambridge, MA 02140,

and to emphasize that they have also published:

'Non-Stock Production,' by Shigeo Shingo; 'New Production System: JIT, Crossing Industry

Boundaries,' by Isao Shinohara;

'Just-In-Time for Today and Tomorrow,' by

Taiichi Ohno and Setsuo Mito;

'Management for Quality Improvement: The 7

New QC Tools,' by Shigeru Mizuno;

'TQC Wisdom of Japan: Managing for Total

Quality Control,' by Hajime Karatsu;

'Workplace Management,' by Taiichi Ohno;

'Inside Corporate Japan,' by David J. Lu; and some others.

The more I study these remarkable books, the more I become convinced that management is technology capable of evolution, environmental embedding and human-systems interactions. As technology it is co-evolving with its own requisite support net, so that any particular management system relies on harmony with its own supportive business ecosystem. All other dimensions, cultural, behavioral, political and informational, do impart some structural differentiation, but remain necessarily secondary to management system's organizational performance.
Japanese-style management is neither 'Japanese' nor 'Eastern', but represents the best American and Western management traditions which were dominant and thriving in the West well into the twenties and thirties in this century.

During the crisis and war times, these 'freemarket' management traditions were abandoned to the more expedient and simpler hierarchical command systems based on enhanced specialization, mass production/consumption, external debt financing, and so on. Instead of optimal design and continuous improvement of systems we have limited our efforts to 'optimization' of a given (mandated, commanded or a priori fixed) system.

Only in the late eighties is U.S. business management beginning to rediscover its own 'roots': customer service, continuous product and service quality improvement, intracompany markets, competition and self-management, financial independence and self-reliance, strategic flexibility and real teamwork. Knowledge has now become the dominant form of capital and the hierarchical command structures of the earlier era or labor dominance are being rapidly discarded by progressive economies.

I close by saying that in the era of global competition there is either bad or good (i.e., competitive) management and no artificially induced 'American vs. Japanese' dichotomies are capable or worthy of survival.

Milan ZELENY

Fordham University at Lincoln Center New York City, NY 10023, USA

Lyman W. Porter and L.E. McKibbin, Management Education and Development. Drift or Thrust into the 21st Century? New York, McGraw Hill, 1987, 372 pages.

Many schools of business are planning for the decades ahead. Therefore, it is fitting to review Porter and McKibbin's book, where they assess the progress made in business and management education in the last 25 years. 
In what follows, I will try to provide a summary of the book in the hope that it will become the focus of our efforts to improve our own School of Business and Public Administration.

The book is the outcome of a three-year study commissioned by AACSB on the future of management education and development. It focuses on work carried out in colleges and universities as well as other educational delivery systems, such as corporations and third-party providers. It also covers the area of Executive Education programs.

As Professor J.E. Howell states in the Foreword:

'All institutions must adapt to changing conditions if they are to merit legitimacy and support, and higher education is no exception. But continuous self-evaluation and concomitant actions are particularly necessary for business schools as they struggle with changes in a variety of dimensions - student abilities and aspirations, faculty strengths and weaknesses, shifting and sometimes volatile social and political institutions, global interdependencies, explosions in science and technology and, not least, evolving management problems and practices'.

The authors have grouped issues around a set of major topics as follows: curriculum (degree programs); students/graduates; faculty; teaching/instruction; research/scholarship; business school relations (within and outside the university); accreditation; and executive education/management development (i.e., life-long learning).

\section{Overview of Findings}

\section{The University Perspective}

\section{Assessments of Present Conditions and Circum- stances}

The authors came away from their university interviews concerned that "there may be too much overall complacency and self-satisfaction' (emphasis in the original):

'The consequences of this self-satisfaction is that currently within universities and their business/management schools there is little perceived need for major changes in the way in which col- legiate management education is carried out' (p. 298).

\section{Outlooks for the Future}

Most deans and faculty members 'appear to have a strong optimistic view of the future relating to their own respective schools'. Their primary aspiration is to increase their relative ranking or visibility in the set of schools within which they compare themselves. The second most frequently goal cited is to 'increase our research efforts and output' (p. 299). And the third most frequently reported goal is to find and continue to develop 'our niche' - what 'this school can do best' given its particular environment and set of circumstances.

\section{Concerns/Problems/Issues}

Two key problems loom large: 1) Funding - especially the capacity to obtain external (nonuniversity) financial support, and 2) the perceived limited supply of qualified faculty members and the ability of the a school to attract the best ones.

Schools interviewed were classified into three categories: Category I schools with PhD Programs, Category II schools which are AACSB accredited, and Category III schools which are not.

Dean and faculty members in Category I schools believed that research was much more strongly emphasized than teaching in their schools, while the reverse was true for schools in Categories II and III. Schools in all three categories expect that, in the future, their schools 'will move to more research/ teaching balance' (p. 300).

In curriculum matters, deans in Category I schools showed stronger preference in favor of curriculum breadth and a substantial liberal arts background for their students, while Category II schools appeared to be more concerned about whether there was enough specialization, particularly in the MBA curriculum.

Category I schools believed that, currently, there is an overemphasis on quantitative subject matter and that the amount of emphasis on the international component in the curriculum should be increased. On the other hand, Category II respondents most often wanted more attention paid to management information systems in their curriculum. 
In general, the authors report that all respondents gave positive ratings and assessments of how 'business/management schools are doing their job today in the U.S.' For exact details about the differences and similarities among respondents, the readers are referred to the book reviewed herein.

\section{The Corporate Perspective}

\section{Overall Perspective}

By and large, members of the corporate world are neither highly satisfied nor highly dissatisfied with the quality of university-based management education in this country. Most high-level corporate executives think that behaviorally oriented subject matter should be emphasized in the curriculum more. Most think that the amount of current emphasis on quantitative-oriented subject matter is about right, although there is a fairly sizable minority who think that this emphasis should be reduced. There is considerable and widespread support for maintaining what is perceived to be a strong emphasis on developing students' analytical skills (p. 303).

Corporate respondents are moderately positive about the quality of BBA and MBA graduates turned out.

The corporate community support the idea that research should be one of the major missions of business schools but they report 'that to data they have not noticed much impact of this research on them or their companies. In effect, they typically claim that they can safely ignore most business school research with impunity' (p. 304).

Further attention must be paid to relations with the business community. On the subject of Executive Education/Management Development, companies thought the major advantage of such programs resides in the fact that their managers can interact with those of other companies, and the major disadvantage as the lack of information relevant to company-specific issues (p. 304).

\section{Criticisms of University-Based Management Edu- cation}

As a result of their research, the authors offer the following criticisms as having at least some degree of validity:
- There is a lack of meaningful integration across functional areas.

- Insufficient attention is paid in the curriculum to managing people and the development of leadership skills.

- Insufficient attention is paid to the 'international component'.

- Business school graduates have overly high expectations about how they will be treated and what they will receive in terms of challenging jobs and rapid advancement when they begin their corporate sector careers.

- New younger faculty members are too narrowly educated in a functional specialty.

- Faculty members lack 'real-world' business experience.

- Faculty research is too heavily oriented to the academic community as an audience and its products are largely irrelevant to the business community.

- Business schools and their faculty do not interact enough with the business community.

The following are criticisms which were voiced by respondents but which the authors claim are not supported by their data:

- Business Schools place too much emphasis on analytical skills. The authors thought that what respondents really meant was not to see these skills diminished, but, rather, other abilities added (p. 309).

- Business schools do not develop their students' communications skills sufficiently, although they noted a definite improvement in this regard in the past 5 years or so.

- Faculty in their classes and teaching activities do not pay sufficient attention to the real world of business. 'What should be a goal is to challenge current practices in order to make them better and more productive' (p. 309). (Emphasis in the original).

\section{Conclusions}

The authors stressed the need for strategic planning. Schools need to take into account:

- Greater accountability demanded of all institutions. 
- Higher costs and a shift in the burden of who pays.

- The increasingly important role of universities in regional, national and international economic development.

- International relationships and globalization of management.

- Changing pedagogical methods through developments in communications technologies.

- Increasing emphasis on entrepreneurial activities.

- Changing demographics.

The report concludes by commenting on what they call 'Undernourished Emphases' as follows:

\section{Breadth}

Graduates are unwittingly insensitive to the impacts of outcomes on factors other than the bottom line'. Not enough attention has been paid to the need to broaden the scope of their interests. Business Schools ought to recognize and support the importance of breadth for 'breadth's sake' (p. 316).

\section{The External Organizational Environment}

There needs to be a proportionate interest in attention to the external environment-government relations, societal trends, legal climate, international developments, among other areas (p. 318).

\section{The International Dimension}

More emphasis is needed in the global dimension.

\section{The Information/Service Society}

While the addition of an MIS faculty and an MIS department and units is certainly necessary, it is the authors contention that: 'the trend toward an information-rich external and internal organizational environment requires a broader response than merely the insertion of courses in the curriculum'.

\section{Cross-Functional Integration}

The need for business education to provide more attention to an 'integrated' approach to problems that cut across specific functional areas.

\section{'Soft' (People) Skills}

Schools ought to increase their students' behavioral skills. The authors realize that this cannot be ex- pected to be accomplished in the 2 years that students have in the BBA and MBA programs. They realize that the emphasis should be on 'life-long learning need'. These skills should be 'honed by a variety of recurring development activities and programs, after graduation' (p. 325).

\section{Faculty Preparation and Development}

In terms of faculty preparation and development, the authors thought that business schools collectively have made definite and commendable progress in upgrading the quality of faculties during the past few decades. They, of course, believe that there is room for definitive improverment. The authors emphasize that 'life-long learning' applies as much to business faculty members as it does to students and to corporate executives. Schools should help their faculty to keep abreast of developments in their respective fields. Overall, it seems apparent that is not lack of development needs for faculty, regardless of the type of school in which they are located, and that any efforts directed at responding to such needs must be appropriately adapted to the specifically identified mission and objectives of the particular school.

\section{Accreditation}

Concerning accreditation by AACSB, the authors noted that the positive impact of accreditation at the 'threshold level' is 'clear and impressive' [Ed: 'Threshold' refers to those schools striving for accreditation], although they also noted the reduced incentive to improve quality 'once a school is well established as an accredited member' (beyond the threshold). They also noted the ignorance or indifference of corporations and the general public to the differences between accredited and non-accredited institutions.

The authors call for the AACSB accreditation to be better understood and for more disclosure to show the nature and quality of accredited institutions. They also call for an additional threshold with standards significantly above the entry level, as well as a notational scheme for providing key information about a business school. 


\section{Summary}

In summary, readers will be interested in many details of this study, which covers the entire life of business schools, students and faculty alike. The book has details about the intellectual aptitudes of students, the quality evaluation of teaching, etc.

I conclude this review by referring to an AACSB study which was recently concluded and which is called the Outcome Measurement Project. It 'resulted in the development of two sets of measurement tools intended to assist business schools in assessing how well they are meeting their educational objectives in terms of students' acquired knowledge and personal skills and characteristics' (p. 159).
Many schools of business are in dire need of better evaluation tools to improve the job of providing quality business and management education. Therefore it is fitting that they should investigate whether this tool could be adapted to their own environment.

The book reviewed in this column should serve as an inspiration to try new ideas and to implement the 'life-long learning' concept which it propounds.

John P. van GIGCH Department of Management California State University Sacramento, CA 95819, USA 